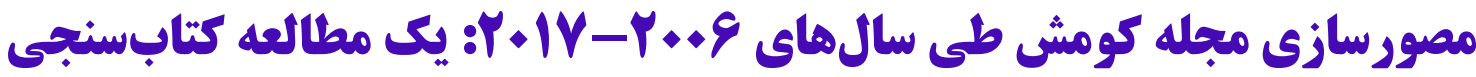

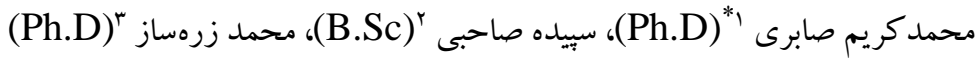

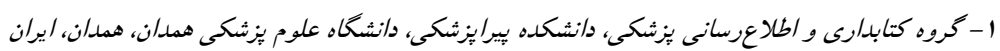

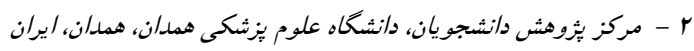

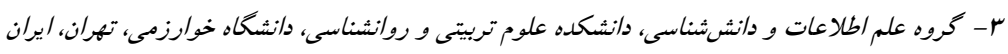

\section{ק్קيد}

هدف: مطالعه حاضر با هدف تحليل كتابسنجى مجله كومش به عنوان يكى از مجلات قديمى و معتبر علوم يزشكى كشور انجام شده است.

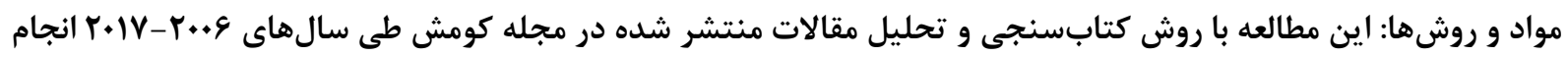

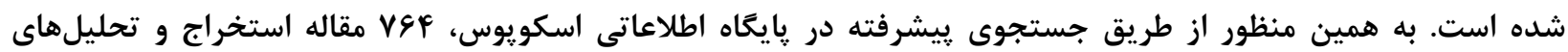

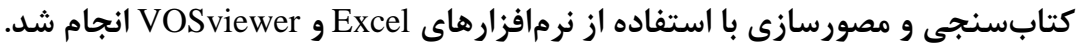

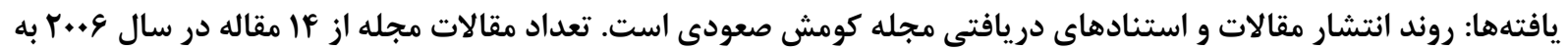

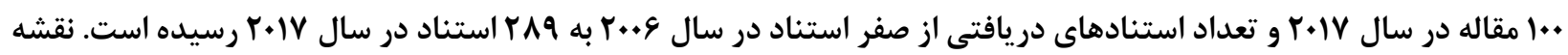

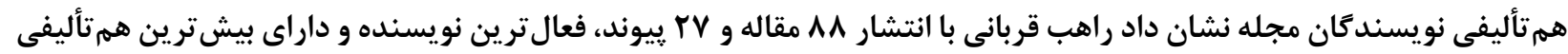

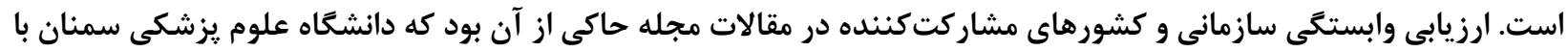

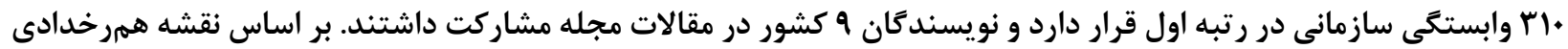

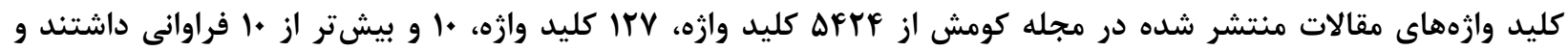

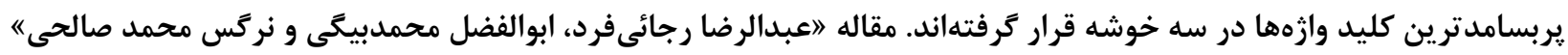

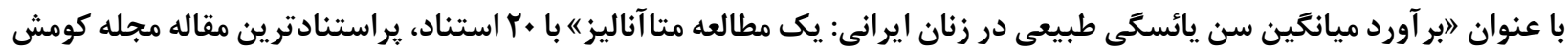

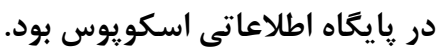

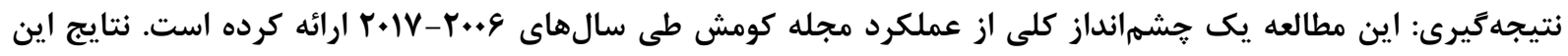

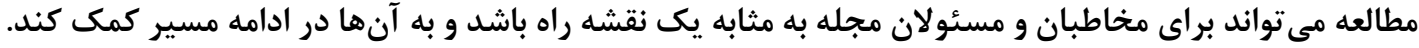

وازههاى كليدى: كتابسنجى، مصورسازى دادهها

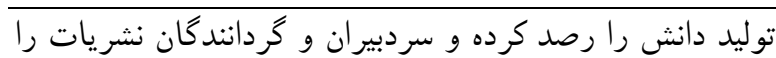

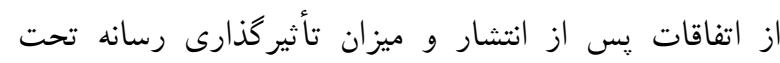

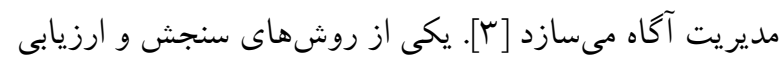

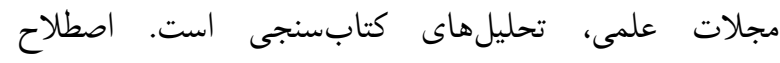

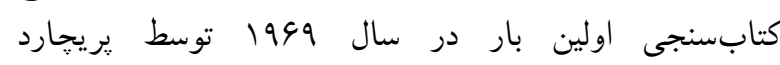
ابداع شد. كتابسنجى حوزهاى است كه مجموعهاى (Pritchard)

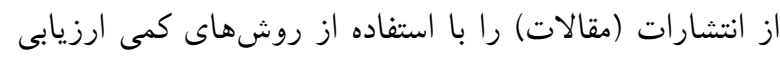

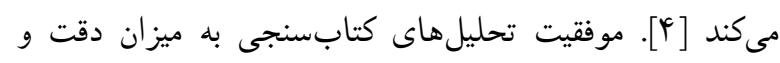

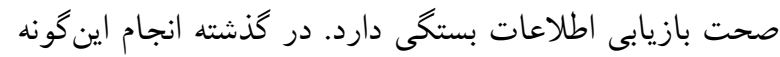

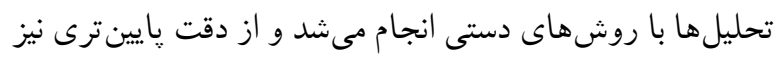

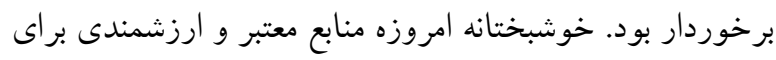

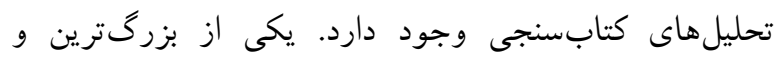

\section{مقدمه}

مجلات علمى بدون ترديد يكى از فرآيندهاى مهم تبادل

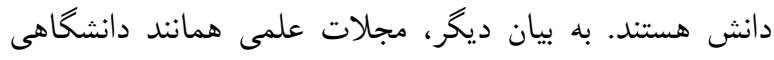

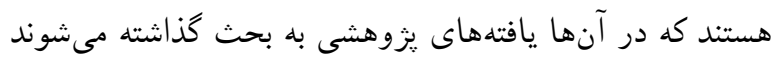

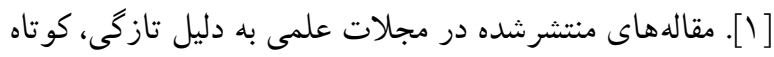

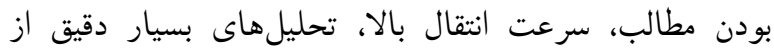

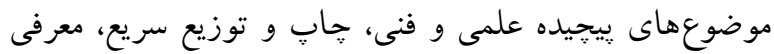

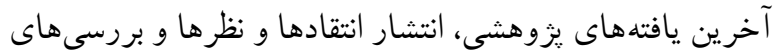

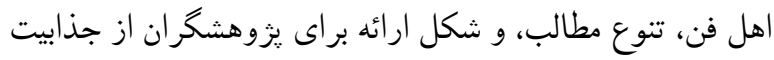

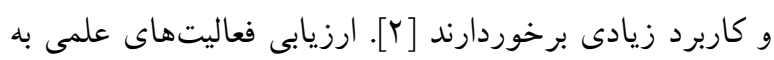

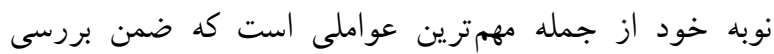

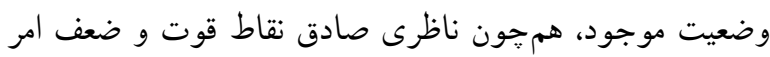


(1) (1) همكارى گروهى نويسندكان مقالات تأليفى مجله

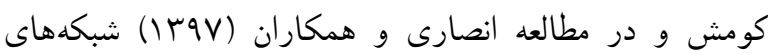

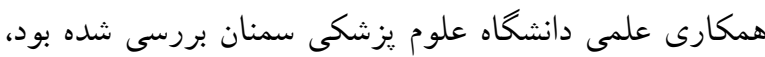
اما مطالعه حاضر در نظر دارد در يكى ارزيابى جامع و با استفاده

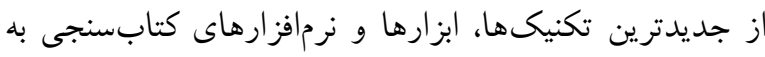

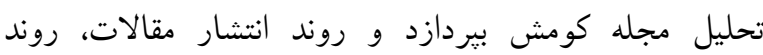

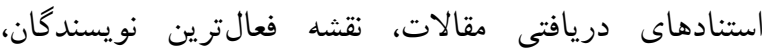
يربسامدترين وابستخى هاى سازمانى و .... را تحليل نمايد.

\section{مواد و روشها}

يزوهش حاضر يك مطالعه كتابسنجى در مورد مجله كومش با كد اخلاق IR.UMSHA.REC.1397.475 است. در مورد اين مطالعه، VGY مقاله منتشر شده در مجله كومش طى سال مالهاى

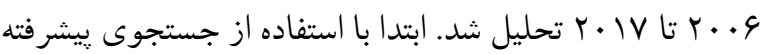
در يايخاه استنادى اسكويوس، مقالات مورد نظر استخراج

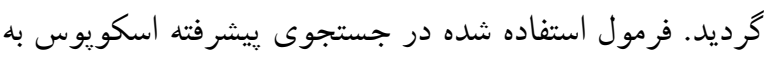
شرح ذيل بود: SRCTITLE (koomesh) AND PUBYEAR > 2005 AND PUBYEAR < 2018

بعد از انجام جستجو، مشخصات تمام مقالات بر اساس

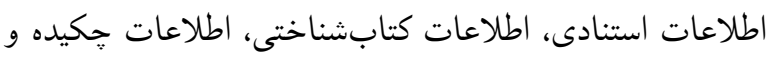

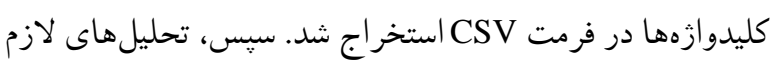
با استفاده از نرمافزار Excel و VOSviewer انجام شد. در اين مطالعه كتابسنجى، توزيع فراوانى و روند انتشار انتشار

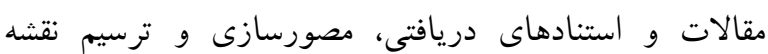

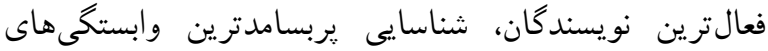
سازمانى، مصورسازى و ترسيم نقشه كشورهاى مشاركتكننده

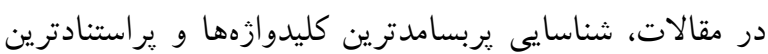

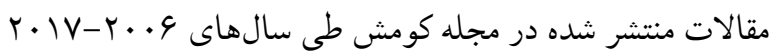

\section{تنايج}

در شكل 1، روند انتشار مقالات مجله كومش طى سالهاى

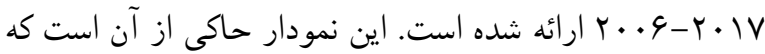
روند انتشار مقاله در مجله كومش صعودى است و تعداد مقالات

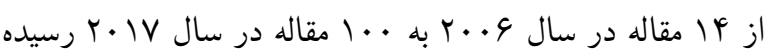

توزيع فراوانى مقالات منتشر شده در مجله كومش در جدول

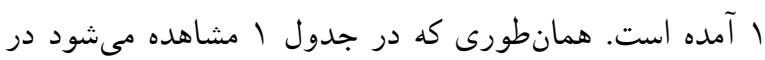

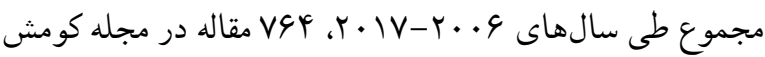

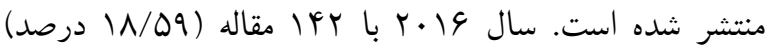

رايجترين منابع براى مطالعات كتابسنجى پِايخاه استنادى

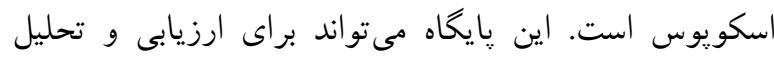

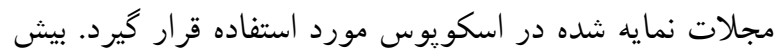

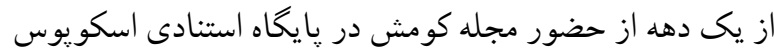

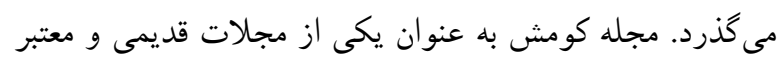

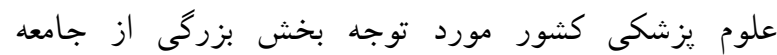

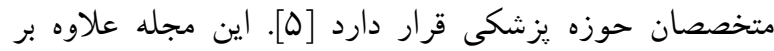

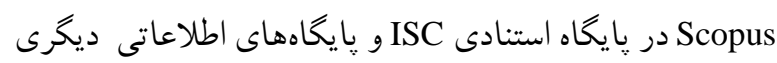
ماند EMBASE, DOAJ, Index Copernicus, SID, Iranmedex, Emro, CABI (UK), Magiran,

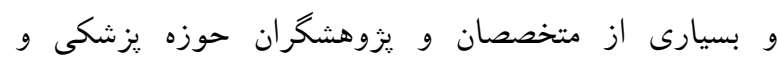
يير ايزشكى كشور در اين مجله حضورى ير رنخ و اثر گذار دارند. بر اين اساس، مطالعه حاضر در نظر دارد مجله كومش را بارئ

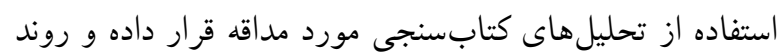
انتشار مجله رادر يك دوره دوازده ساله بررسى نمايد. مرور

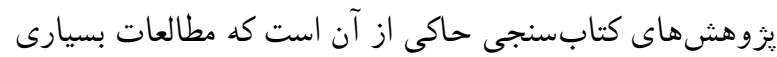

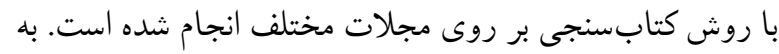

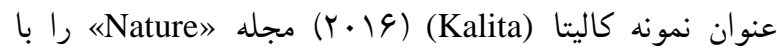

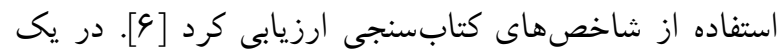
مطالعه كتابسنجى ديخر، زانگ و همكاران (Yhang et al)

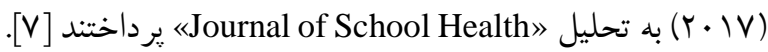
همكاران تانگ نيز با روش كتابسنجى مجله (Y.|N) (Tang et al)

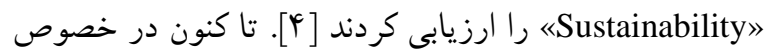
مجله كومش يك تحليل كتابسنجى جامع انجام نشده است. از

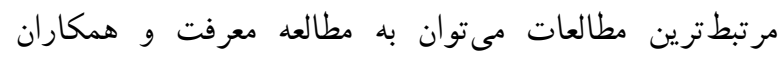

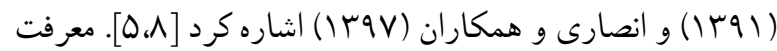

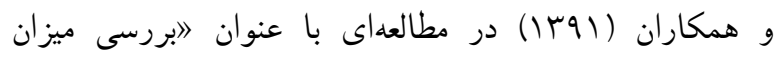

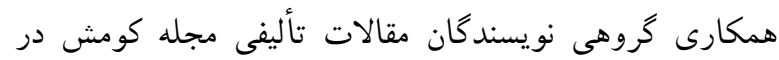

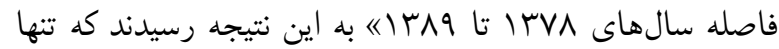

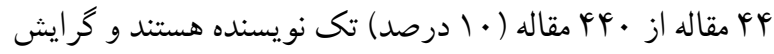

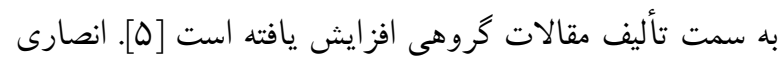

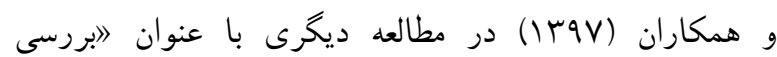

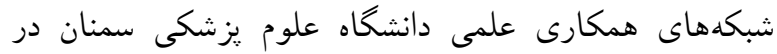

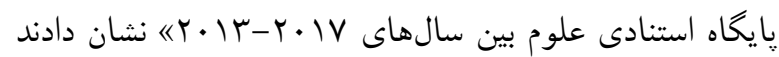

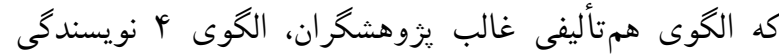

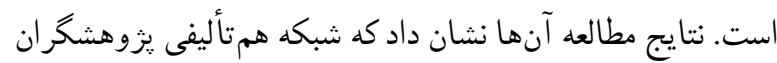

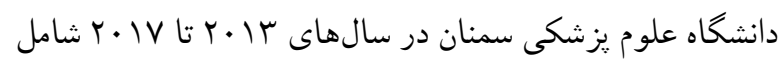
OV

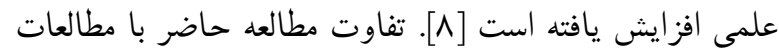
مذكور [^، [0، در اين است كه در مطالعه معرفت و همكاران 


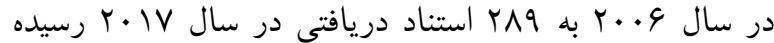
است.

جدول r. توزيع فراوانى استنادهاى دريافتى مقالات مجله كومش مانك

\begin{tabular}{|c|c|c|c|}
\hline ميانكَين استنادها در & استنادهاى دريافتى & مقالات & سال \\
\hline . & . & If & $r . . q$ \\
\hline . & . & Q) & $r \cdots V$ \\
\hline $.1 \cdot r$ & 1 & is & $r \cdots \wedge$ \\
\hline - & . & Fa & $r \ldots q$ \\
\hline.$/ 1 \mathrm{~V}$ & $\Lambda$ & FV & $r \cdot 1$. \\
\hline rאן. & $r$. & 41 & $r .11$ \\
\hline .19. & re & 4. & $r .1 T$ \\
\hline $1 / 19$ & 90 & $r \Delta$ & $r \cdot \| r$ \\
\hline$\cdot / 199$ & $V r$ & 94 & $r \cdot \| r$ \\
\hline $1 / \Delta T$ & $1 \cdot 1$ & VI & $r \cdot 10$ \\
\hline $1 / \Delta \Lambda$ & TYY & IFT & $r .19$ \\
\hline r/A & rی9 & $1 \ldots$ & $r . I V$ \\
\hline $1 / \cdot 1$ & NYF & VGF & جمع \\
\hline
\end{tabular}

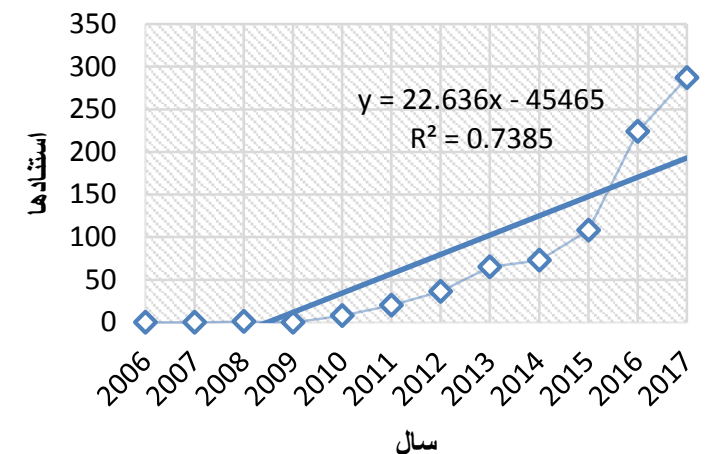

شكل r. روند استنادهاى دريافتى مقالات مجله كومش

در جدول "، مشخصات • ا نويسنده فعال مجله كومش ارائه شده است. منظور از نويسندكان فعال نويسندكانى است كه داراى بيشترين انتشارات هستند. مشخصات ارائه شده در جدول بات،

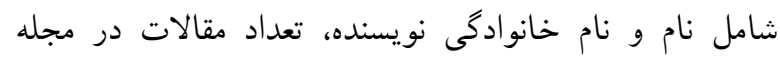
كومش، اجز ايندكس، تعداد كل مقالات در نام اسكويوس، تعداد استنادهاى دريافتى در اسكويوس و وابستخى سازمانى است.

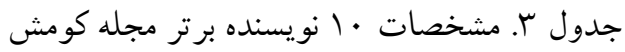

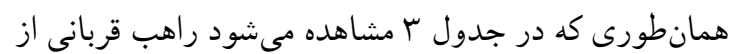
دانشخاه علوم يزشكى سمنان با انتشار M M مقاله، فعالترين

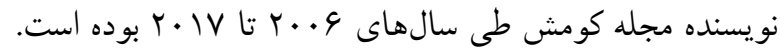

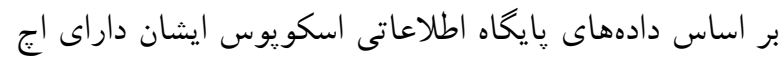

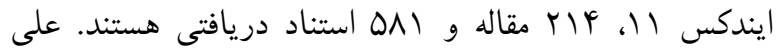
رشيدى يور با انتشار بr مقاله و مجيد ميرمحمدخانى با انتشار 19 مقاله، به ترتيب در رتبههاى دوم و سوم فعال ترين نو يسندگًان

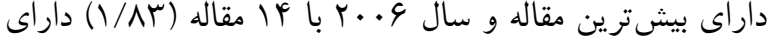
كمتر ين مقالات هستند.

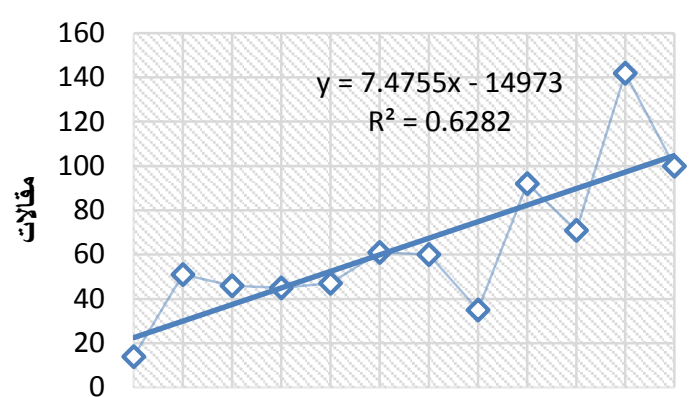

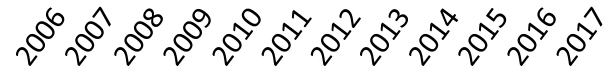

سال

شكل ا. روند انتشار مقالات مجله كومش

\begin{tabular}{|c|c|c|c|c|}
\hline I/Ar & I/Ar & If & If & $r . . q$ \\
\hline$N / D 1$ & 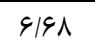 & 90 & DI & $r \cdots V$ \\
\hline $\mid F / \Delta r$ & G1.r & 111 & 48 & $r \cdots \wedge$ \\
\hline$r \cdot / K T$ & $0 / \wedge 9$ & 109 & $r \Delta$ & $r \ldots q$ \\
\hline T\&/DV & $9 / 10$ & $r \cdot r$ & FV & $r \cdot 1$. \\
\hline$r F / \Delta Q$ & $V / 91$ & TEY & 91 & $r \cdot 11$ \\
\hline$F T / F)$ & $V / \wedge \Delta$ & TrF & c. & $r \cdot I r$ \\
\hline $48 / 99$ & $F / \Delta \Lambda$ & $r \Delta q$ & ro & $r \cdot r^{\prime}$ \\
\hline$\Delta q / \cdot r$ & $\mid r / \cdot F$ & $f \Delta 1$ & 95 & $r \cdot \mid r$ \\
\hline GN/Kr & $9 / 7 q$ & DTr & $v_{1}$ & $r \cdot 10$ \\
\hline $18 / 91$ & $1 N / 09$ & Gq4 & IFT & $r .19$ \\
\hline $1 \ldots$ & $1 \pi / \cdot 9$ & $V G 4$ & $1 \cdots$ & $r . I V$ \\
\hline- & $1 \ldots$ & - & Vat & جمع \\
\hline
\end{tabular}

در جدول ب توزيع فراوانى استنادهاى دريافتى مقالات مجله

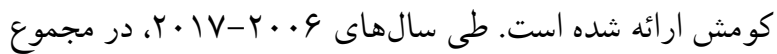

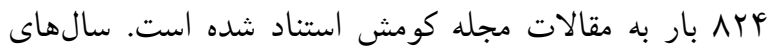

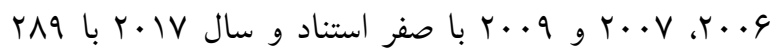
استناد به ترتيب داراى كمترين و بيشترين استناد دريافتى

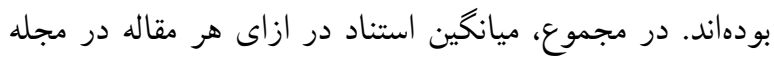

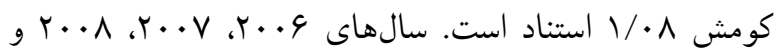

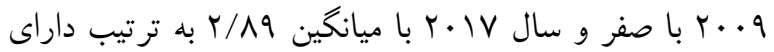

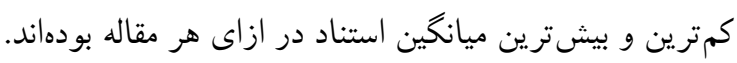

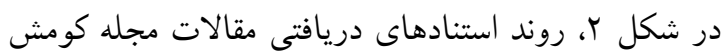

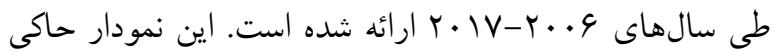

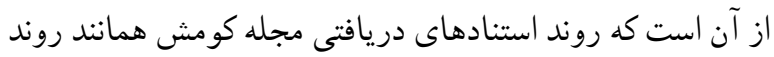
انتشار مقالد صعودى است و تعداد مقالات از صفر استناد دريافتى درئن 


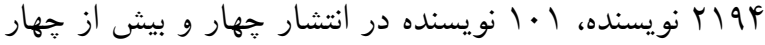

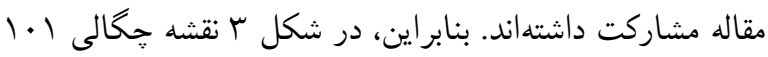
نويسنده فعال مجله كومش (نويسندگان با حداقل جهار مقاله)

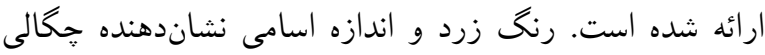
بيشتر (مقاله بيشتر) نويسندكان است. در نمودار با، راهب الهاب

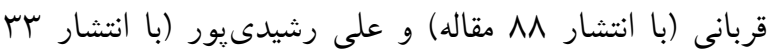

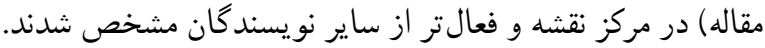

مجله كومش قرار دارند. مجتبى ملك با ها مقاله، اميرهوشنگ

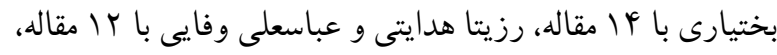

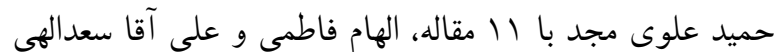
با 9 مقاله در رتبههاى بعدى قرار دارند. براى مصورسازى و ترسيم نقشه فعال ترين نويسندكان مجله

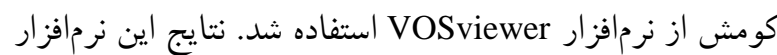

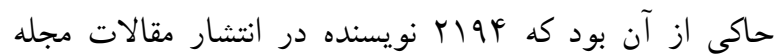

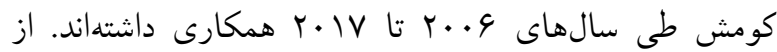

جدول r. مشخصات · ا نويسنده برتر مجله كومش

\begin{tabular}{|c|c|c|c|c|c|}
\hline وابستخى سازمانى & تعداد استنادها در & تعداد كل مقالات در & ايندكس & مقالات & 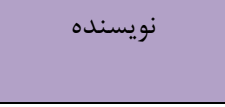 \\
\hline دانشعاه علوم يزشكى سمنان & $\Delta \wedge 1$ & rIf & 11 & $\wedge \Lambda$ & راهب قربانى \\
\hline دانشگاه علوم يزشكى سمنان & 1990 & 1199 & TH & זr & على رشيدى يور \\
\hline دانشعاه علوم يزشكى سمنان & ler & $9 V$ & $\Delta$ & 19 & مجيد ميرمحمدخانى \\
\hline دانشكاه علوم يزشكى ايران & 499 & $\Lambda \mu$ & ir & 10 & مجتبى ملك \\
\hline دانشكاه علوم يزشكى سمنان & rrq & re & $\wedge$ & If & اميرهوشنَ بختيارى \\
\hline دانشكاه علوم يزشكى سمنان & tr & $r 1$ & r & ir & رزيتا هدايتى \\
\hline دانشكاه علوم يزشكى سمنان & $1 \cdot 9$ & vr & IV & it & عباسعلى وفايى \\
\hline دانشگاه علوم يزشكى شهيدبهشتى & $|\& T|$ & $\mid \vee \wedge$ & 19 & 11 & حميد علوى مجد \\
\hline دانشكاه علوم يزشكى سمنان & $\Delta \varphi$ & 14 & f & 9 & الهام فاطمى \\
\hline دانشخاه علوم يزشكى سمنان & r & $1 \cdot$ & 1 & 9 & على آقا سعدالهى \\
\hline
\end{tabular}

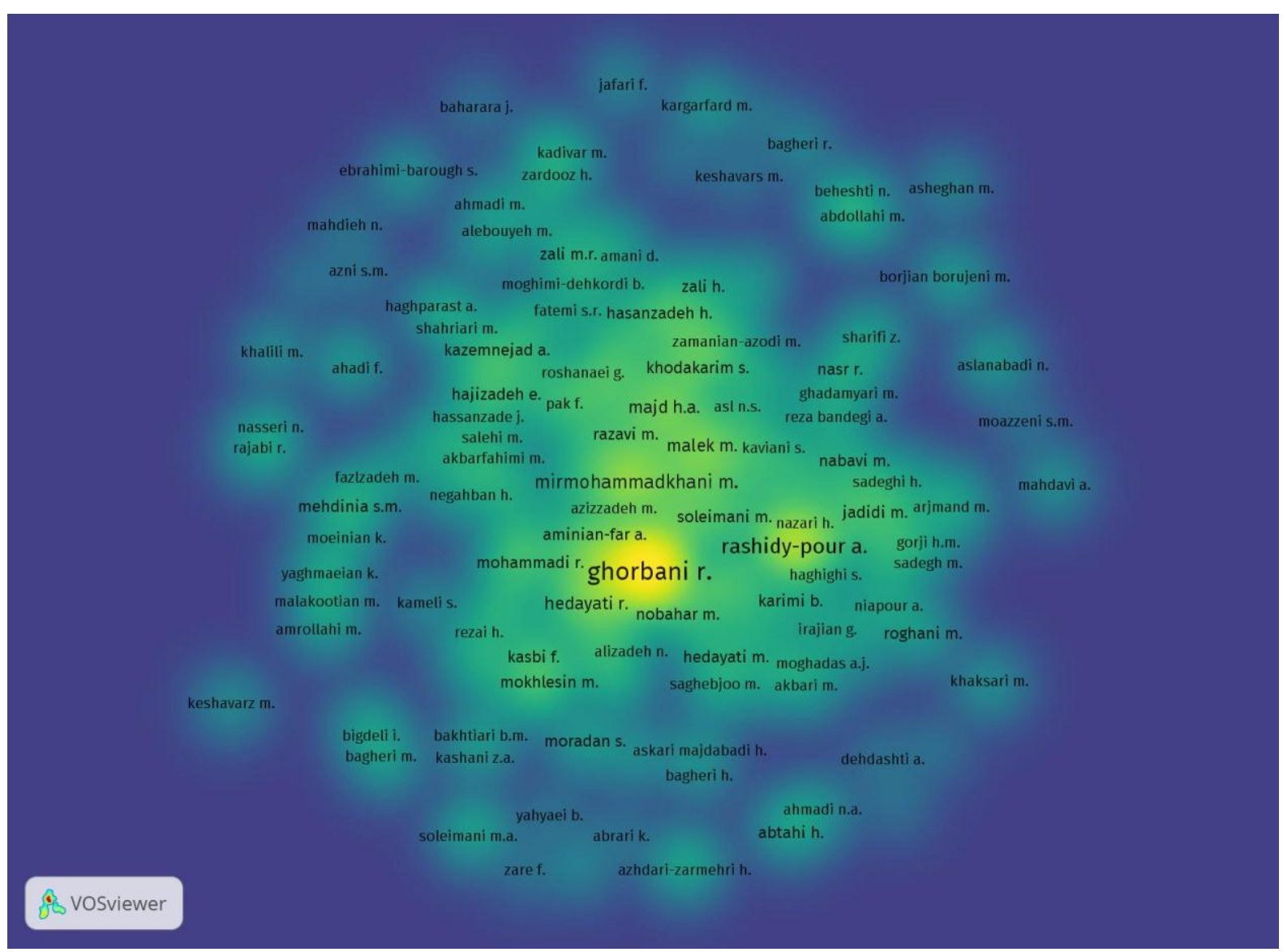

شكل r. نقشه نويسندكان مجله كومش 


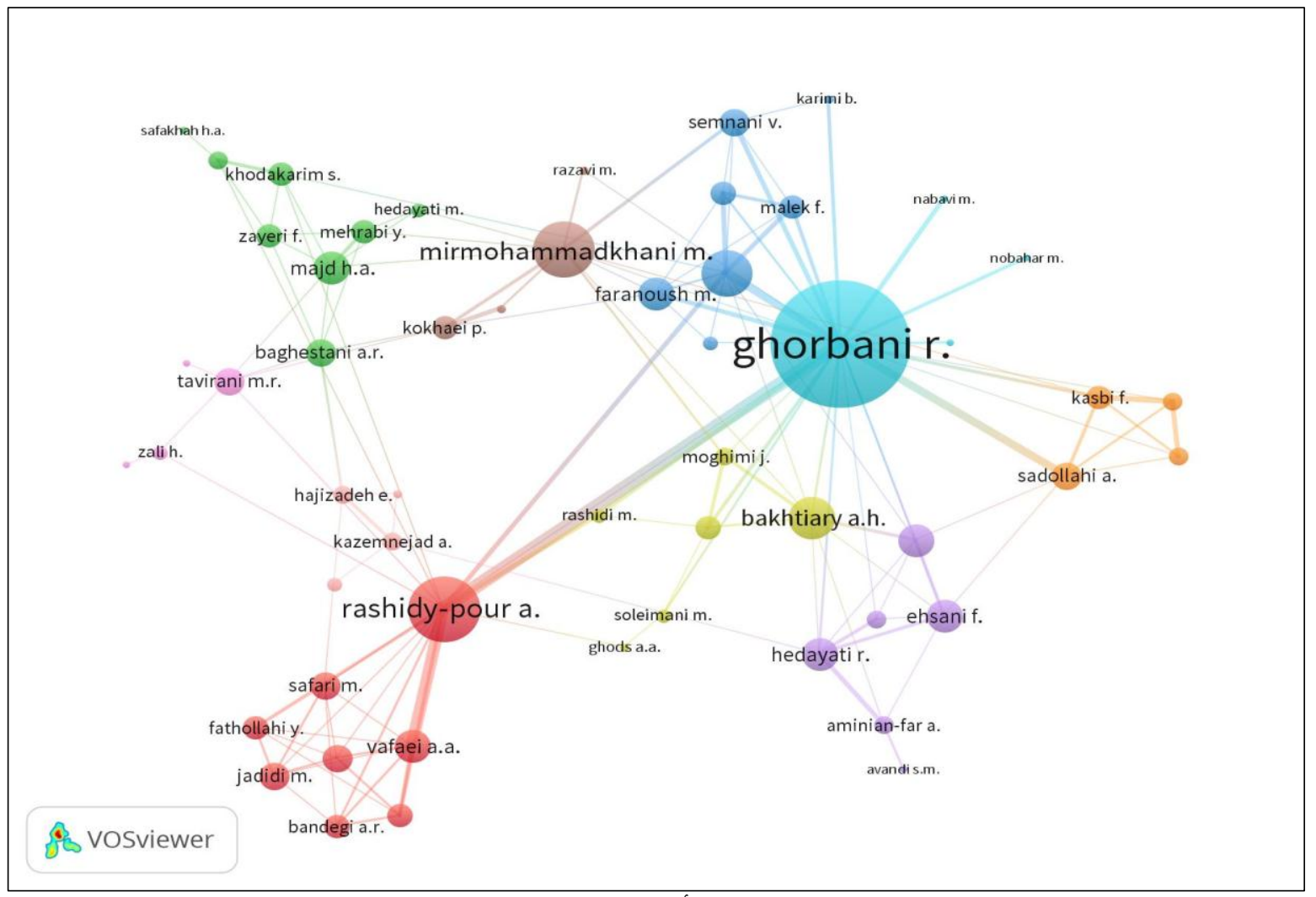

شكل f. نقشه همتأليفى نويسندكان مجله كومش

در جدول F و ابستخى سازمانى مقالات منتشر شده در مجله

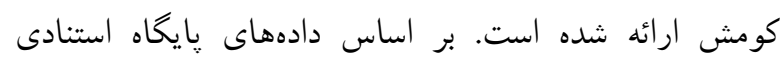

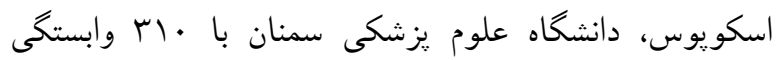

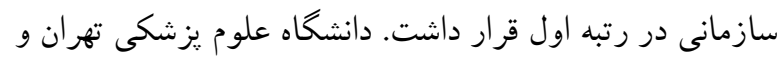

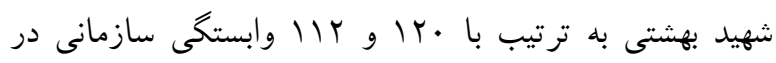
رتبههاى دوم و سوم قرار داشتند.
در شكل † نقشه هم تأليفى نويسندكان مجله كومش نشان

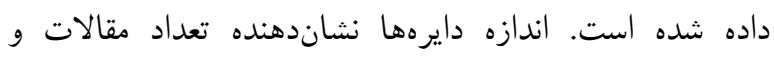

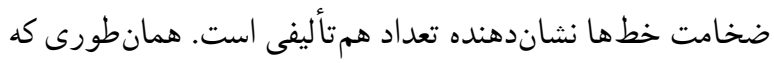

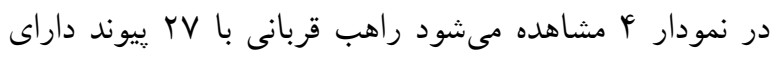

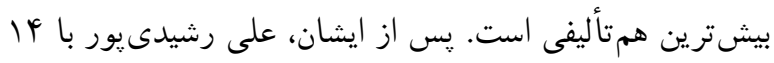

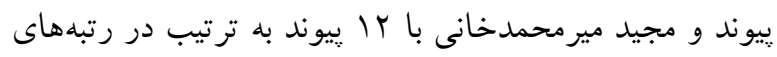

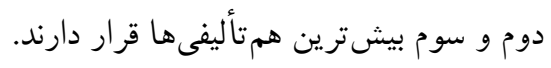

جدول F. دانشخاههاى مشاركت كننده در مقالات مجله كومش دانشاه

\begin{tabular}{|c|c|c|c|}
\hline درصد & فراوانى & دانشخاه & رديف \\
\hline$r \cdot \mid \Delta \Lambda$ & r. & دانشعاه علوم يزشكى سمنان & 1 \\
\hline$|\Delta / V|$ & IT. & دانشكاه علوم يزشكى تهران & r \\
\hline $14 / 98$ & 114 & دانشًاه علوم يزشكى شهيد بهشتى & r \\
\hline$V / 9 \Lambda$ & 91 & دانشخاه تربيت مدرس & r \\
\hline$\Delta / V \varphi$ & pq & دانشگاه علوم يزشكى ايران & $\Delta$ \\
\hline$r / \Delta \Lambda$ & ra & دانشخاه آزاد اسلامى & द \\
\hline$r / \Lambda$. & $r q$ & دانشخاه علوم بهزيستى و توانبخشى & $v$ \\
\hline r/99 & $r \wedge$ & دانشخاه تهران & $\wedge$ \\
\hline$r / 4$. & re & دانشكاه علوم يزشكى اراى & 9 \\
\hline$r / T V$ & ro & دانشخاه سمنان & $1 \cdot$ \\
\hline$r / V \Delta$ & rI & دانشكاه علوم يزشكى اصفهان & 11 \\
\hline r/GT & $r \cdot$ & انستيتو غدد درون ريز و متابوليسم & it \\
\hline$r / r G$ & 11 & دانشكاه علوم يزشكى مشهد & Ir \\
\hline
\end{tabular}




\begin{tabular}{|c|c|c|c|}
\hline درصد & 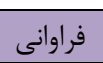 & دانشكاه & رديف \\
\hline 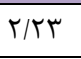 & IV & دانشكاه علوم يزشكى و خدمات بهداشتى درمانى همدان & 14 \\
\hline 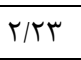 & IV & دانشكاه علوم يزشكى شيراز & 10 \\
\hline 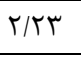 & iv & دانشخاه علوم يزشكى جندى شايور اهواز & 19 \\
\hline$r / \cdot 9$ & 19 & دانشخاه علوم يزشكى كرمان & iV \\
\hline 1/99 & 10 & دانشكاه آزاد اسلامى واحد علوم و تحقيقات & 11 \\
\hline $1 / \mathrm{v}$ & ir & مركز تحقيقات عوامل اجتماعى موثر بر سلامت دانشعًاه علوم يزشكى شهيد بهشتى & 19 \\
\hline $1 / \Delta V$ & ir & دانشكاه علوم يزشكى كاشان & $r \cdot$ \\
\hline $1 / \Delta V$ & ir & ـ دانشعاه يِيام نور & rI \\
\hline $1 / \Delta V$ & ir & دانشگاه علوم يزشكى تبريز & rt \\
\hline $1 / \Delta V$ & ir & دانشخاه علوم يزشكى ايلام & r \\
\hline $1 / 44$ & 11 & انستيتو ياستور ايران & TF \\
\hline $1 / 44$ & 11 & دانشكاه علوم يزشكى شهيد صدوقى & ro \\
\hline $1 / \pi 1$ & 1. & دانشكاه شاهد & TQ \\
\hline $1 / \pi 1$ & 1. & دانشخاه شهيد بهشتى & tr \\
\hline
\end{tabular}

جمهورى קك، مالزى، سنگإيور، كره جنوبى و ايالات متحده آمريكا داشتند.

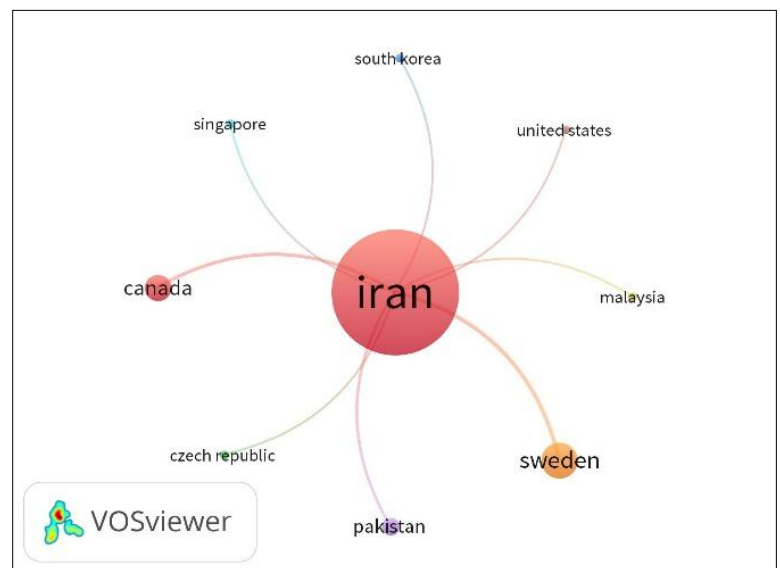

شكل ه. نقشه همتأليفى كشورهاى مشاركت كننده در مقالات مجله كومش

در شكل צ، نقشه همرخدادى كليدوازههاى مقالات منتشر

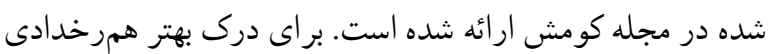
كليدوازهها از تكنيك خوشهبندى استفاده شد. براى آنجام آرام خوشهبندى بايد يك آستانه براى تكرار كليدوازهها تعيين شود.

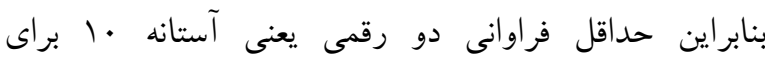

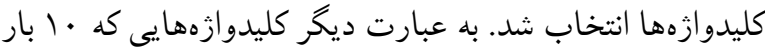

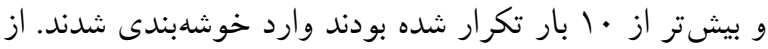
S SFYF

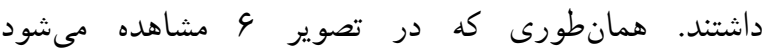
يربسامدترين كليدوازهها در سه خوشه قرار گرفتهاند. اولين و

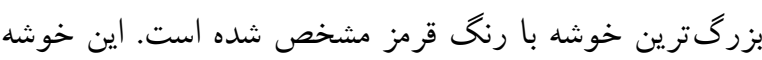
از •4 كليدوازه تشكيل شده است. در اين خوشه دو كليدوازه

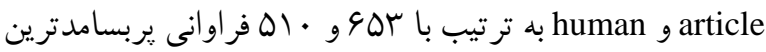

جدول ه، كشورهاى مشاركتكننده در مقالات مجله كومش را نشان مىدهد. بر اساس دادههاى جدول ه، نويسندكان ايرانى در .ادرصد مقالات مجله كومش، مشاركت داشتئهاند. نويسندگان با وابستخى كشور سوئد در ץ مقاله، كانادا ب مقاله،

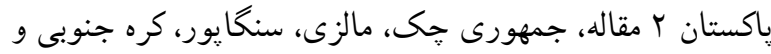

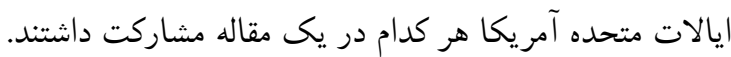

جدول ه. كشورهاى مشاركت كننده در مقالات مجله كومش كت

\begin{tabular}{|c|c|c|}
\hline درصد & تعداد مقالات & 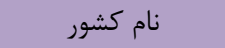 \\
\hline $1 \cdots$ & VGF & ايران \\
\hline$\Delta r$ & r & سوئد \\
\hline rq & r & كانادا \\
\hline re & r & ياكستان \\
\hline r & 1 & جمهورى حك \\
\hline ir & 1 & مالزى \\
\hline r & 1 & سنخايور \\
\hline ir & 1 & كره جنوبى \\
\hline r & 1 & ايالات متحده آمريكا \\
\hline
\end{tabular}

در شكل ه نقشه همتأليفى (Co-authorship) كشورهاى

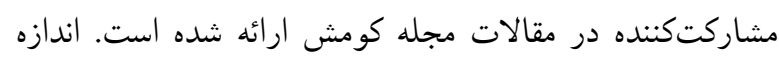

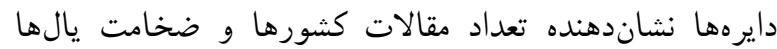

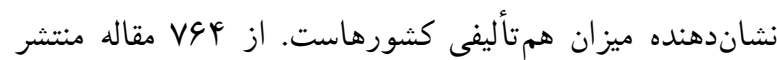

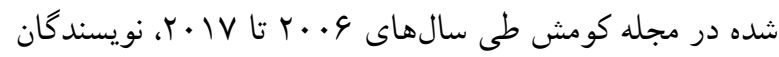
ايرانى در ..1 درصد مقالات حضور داشتند. نويسندكان ايرانى

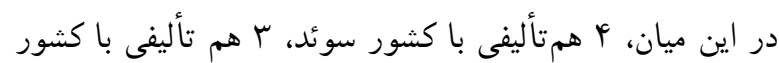

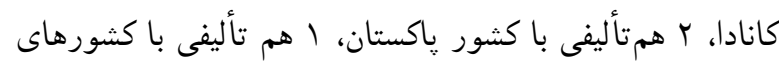


ايرانى: يك مطالعه متآناليز 《با • ب استناد، يراستنادترين مقاله

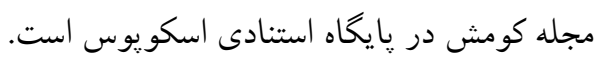

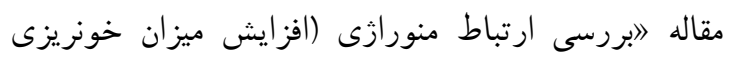

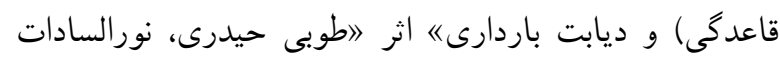

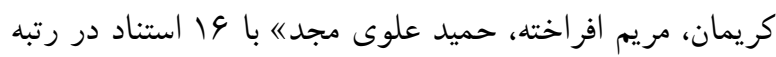

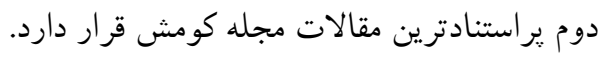
رتبه سوم مقالات براستناد مجله كومش نيز به مقار مقالدهاى

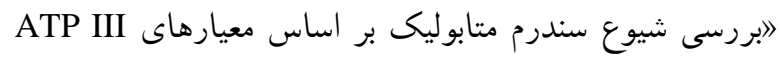
IDF, در استان سمنان / اثر "راهب قربانى، بهاره ابطحى نائينى،

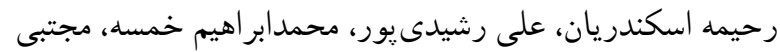

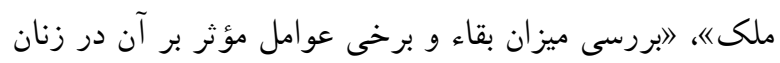

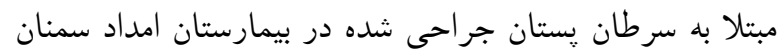

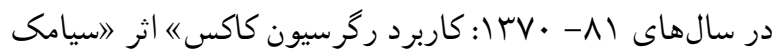

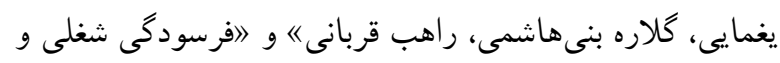

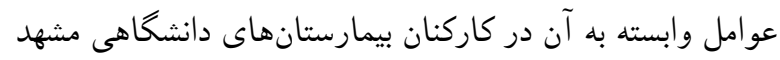

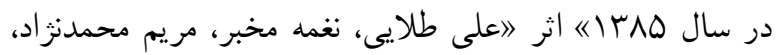

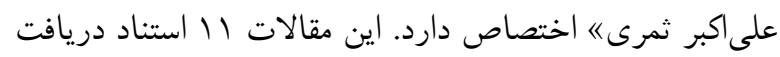

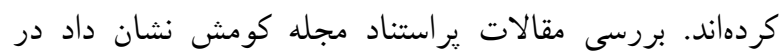

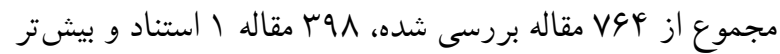

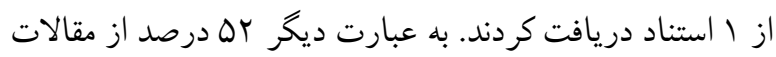
منتشر شده در مجله كومش استناد داشتند.
وازكان بهشمار مىروند. كليدوازههاى ديخرى نيز مانند female،

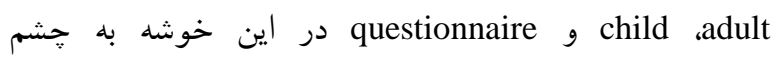
مى خورند. با توجه به كليدوازههايى كه در اين خوشه قرار دارند ايند

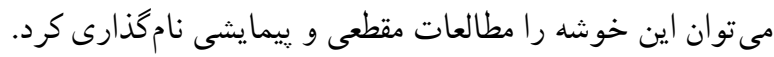

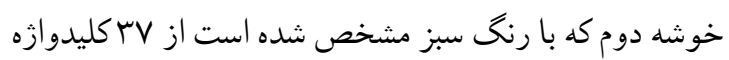
تشكيل شده است. در اين خوشه controlled study

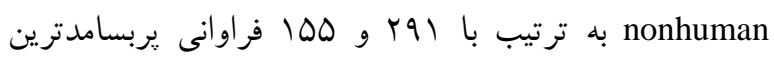

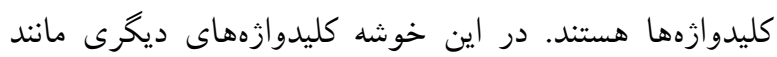
animal experiment animal model دوم را بر اساس كليدوازههاى آن مى توان مطالعات آزمايشخاهى دارند

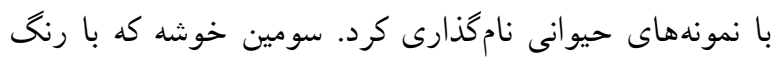

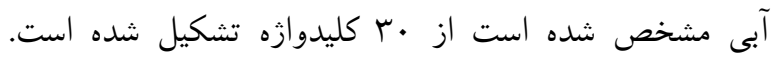

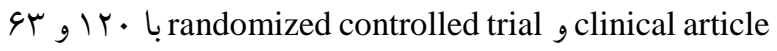
فراوانى بربساهدترين كليدوازههاى خوشه سوم هستند. از ديخر

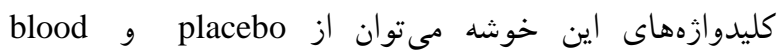
sampling نام برد. اين خوشه ران انيز مى توان مان مطالعات كار آزمايى بالينى ناميد. مشخصات · إمقاله براستناد مجله كومش در جدول 9 ارائه شده است. همانطورى كه در جدول 9 مشاهده مىشود، مقاله

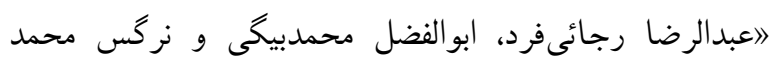

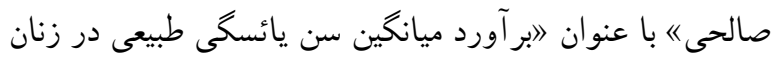

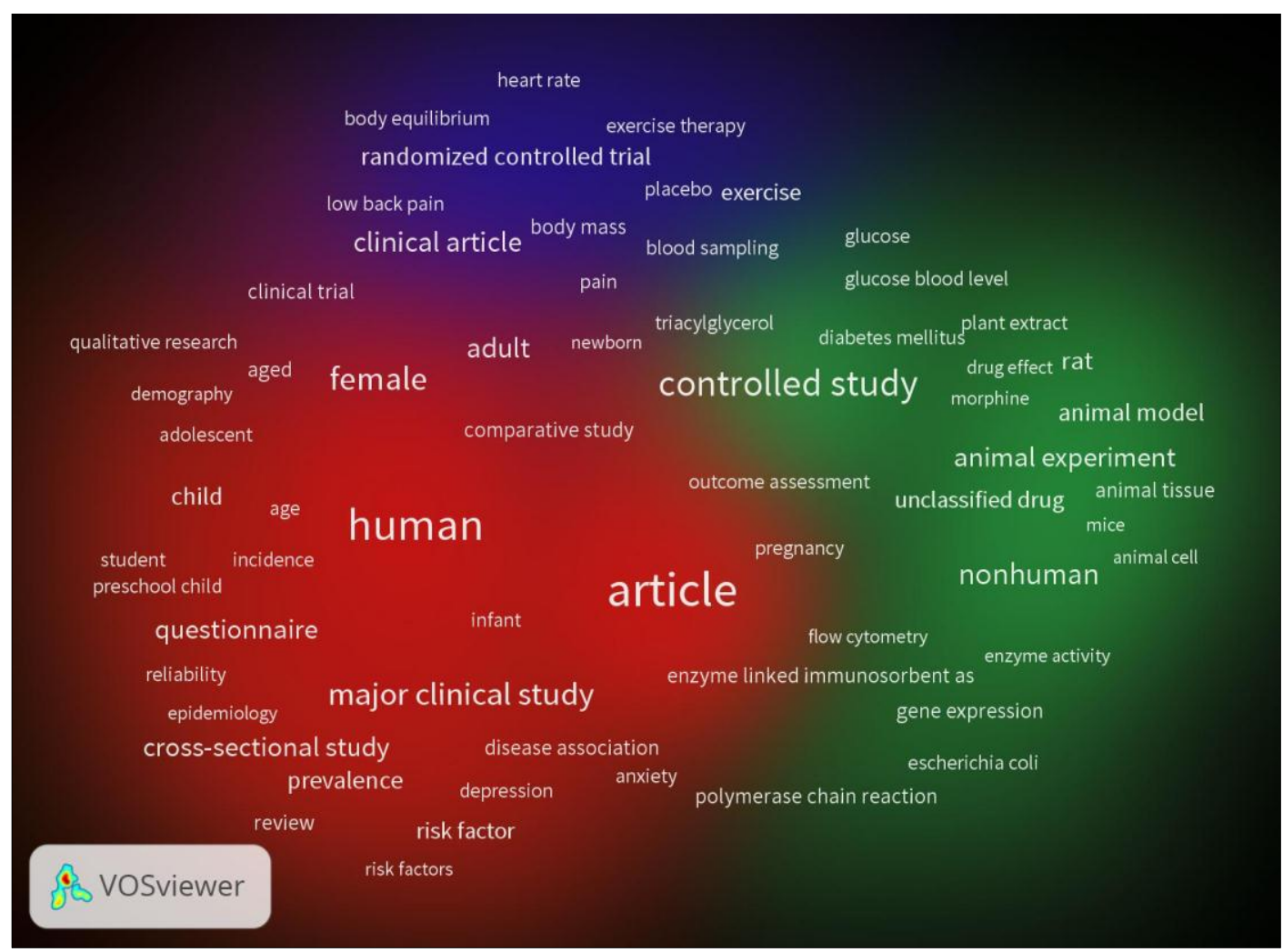

شكل 9. نقشه همرخدادى كليدوازمهاى مقالات منتشر شده در مجله كومش 


\begin{tabular}{|c|c|c|c|c|}
\hline رتبه & سال انتشار & 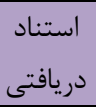 & نويسندكان & عنوان مقاله \\
\hline 1 & $1 r q \cdot(r \cdot 11)$ & $r$. & 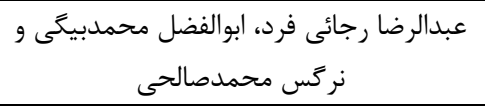 & برآورد ميانگَين سن يائسگى طبيعى در زنان ايرانى: يك مطالعه \\
\hline$r$ & $\|$ |r८ $(\ulcorner\cdot \wedge)$ & 19 & 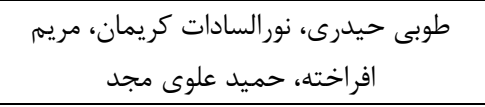 & بررسى ارتباط منورازى (افزايش ميزان خونريزى قاعدگى) و ديابت \\
\hline r & $|r q|(r \cdot \mid r)$ & 11 & 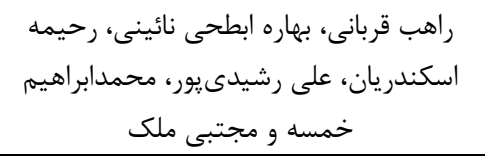 & 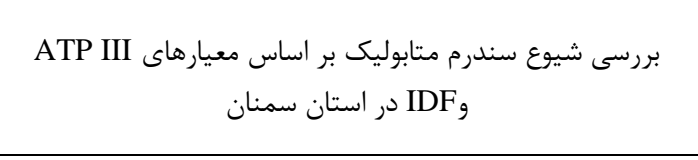 \\
\hline$r$ & $\mid r \wedge q(\ulcorner\cdot \wedge)$ & 11 & سيامك يغمايى، كلاره بنىهاشمى، راهب & 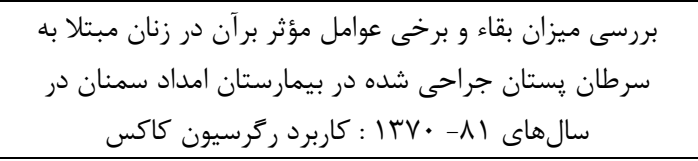 \\
\hline r & $\operatorname{lr} \wedge \vee(r \cdots \wedge)$ & 11 & 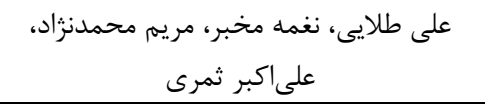 & 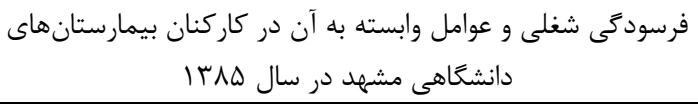 \\
\hline r & $1 r q \cdot(r \cdot 11)$ & 1. & فحمدرضا عسكرى، عيسى محمدى، مسعود & درك بيماران همودياليزى از نقش رفتار يرستاران در سازگًارى \\
\hline r & $1 r q \cdot(r \cdot 11)$ & 1. & ساطمه حميد شريفنيا، علىاكبر حقدوست، حميد حجتى & بررسى ارتباط اختلالات اسكلتى عضلانى با عوامل اركونوميكى در \\
\hline r & $\mid r \lambda v(r \cdot . q)$ & 1. & على اصغر قدس، فاطمه الحانى، منيره انوشه، & بررسى إيدميولوزيك حوادث حين كار در شهرستان سمنان (سال \\
\hline$\Delta$ & $1 r 9 \Delta(Y \cdot 19)$ & 9 & زايرى، سامان معروفى زاده، محدثه شاهرخ آبادى، فريد & رابطهى رضايت از زندگى، اضطراب و كيفيت زندگى نابارورى \\
\hline$\Delta$ & $1 \% \wedge 9(r \cdot 11)$ & 9 & فيروزآبادى، كاظم رسولى شفيعى ارابى، سيد محمد & مغناطيسى كمى شدت تغيرات سيخنال هاى مغزى ناشى از تابش ميدان \\
\hline
\end{tabular}

«Sustainability» و توسط زانخ و همكاران (Y Health»

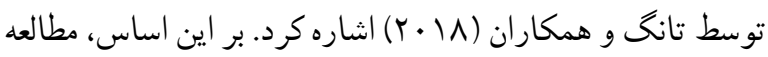

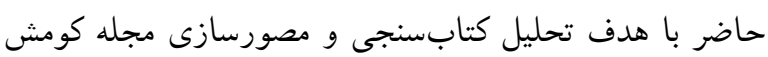
به عنوان يكى از مجلات قديمى و معتبر علوم يز شكى كشى كشور

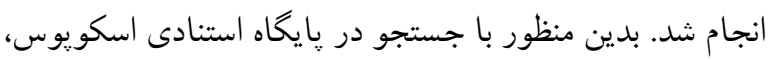

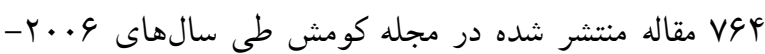

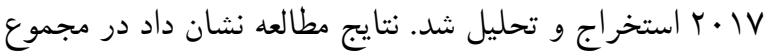

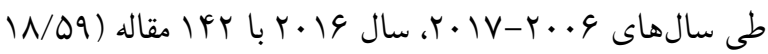

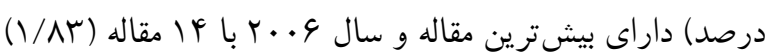
داراى كمترين تعداد مقالات بوده و روند انتشار مقاله در مجله

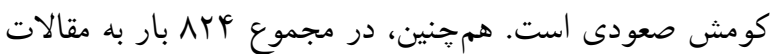

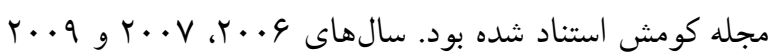

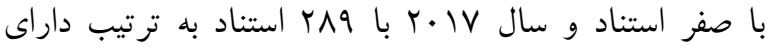

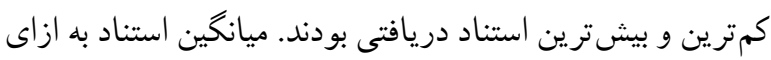

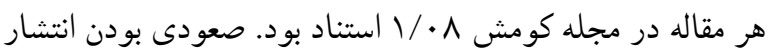

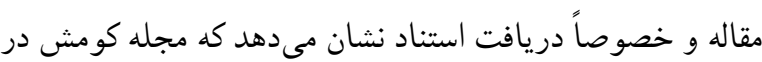
حال يبشرفت است. استناد به عنوان يك شاخص كتابسنجى نشانه اثركذارى يك مجله است. AYF استناد به مقالات مجله

\section{بحث و نتيجه كيرى}

امروزه مجلات علمى به دليل تنوع و اشاعه سريع اطلاعات،

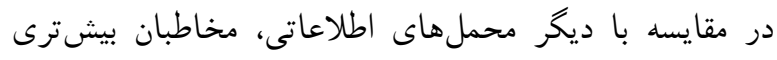

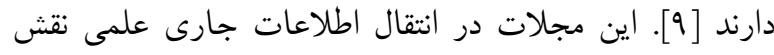

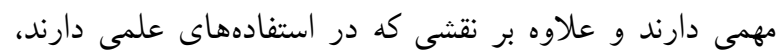

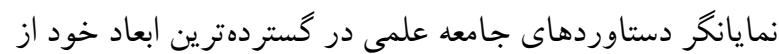

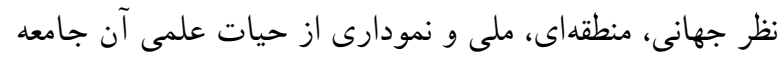

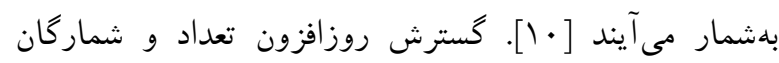

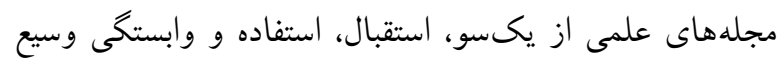

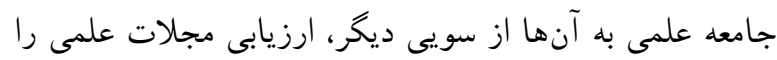

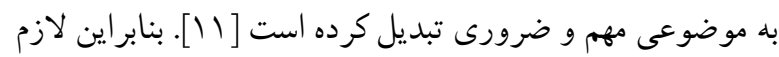

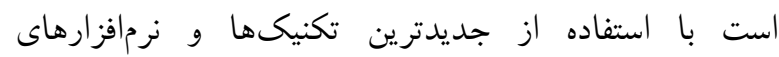

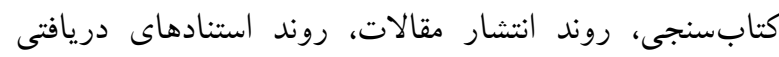

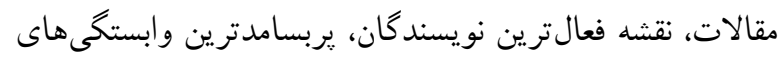

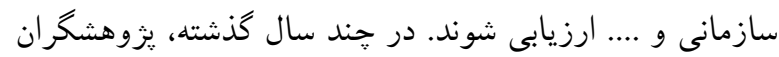

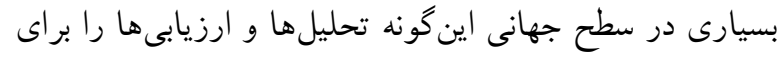

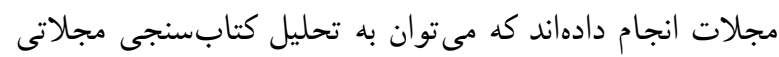
مانند Nature» 
كاستىها و محدوديتهاى مطالعه بايد اشاره كرد كه به دليل

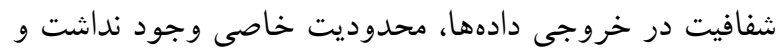

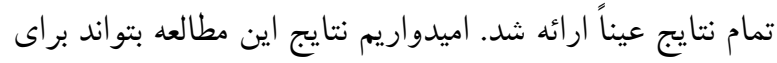

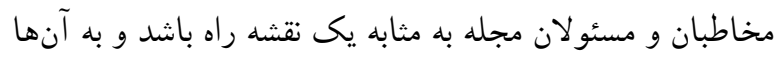
در ادامه مسير كمك كند.

\section{تشكر و قدردانى}

نويسندگان از معاونت تحقيقات و فناورى دانشگاه علوم يزشكى همدان به خاطر حمايت مالى اين مطالعه در قالب طرح شماره QV.AYYFADF تشكر و قدردانى مىنمايند. اين مقاله

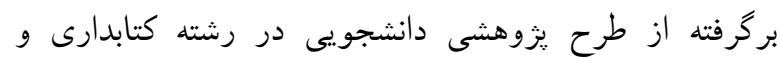
اطلاعرسانى يزشكى است.

\section{منابع}

[1] Van Raan AF. The use of bibliometric analysis in research performance assessment and monitoring of interdisciplinary scientific development. Technol Assessment Theory Pract 2003; 12: 20-29.

[2] Erfanmanesh M, Nojavan F. Qualitative and quantitative status and international visibility of Iranian journals indexed in journal citation reports. Iran J Inf Process Manag 2016; 32: 51-73.

[3] Rashidi A, Mohtashami A, Nazari H, Eftekhari F. investigating the rate of visibility of urmia medical journal articles in Scopus Compared with other medical Journals of northwest medical university of Iran. J Urmia Univ Med Sci 2016; 27. (Persian).

[4] Tang M, Liao H, Wan Z, Herrera-Viedma E, Rosen MA. Ten years of sustainability (2009 to 2018): a bibliometric overview. Sustainability 2018; 10: 1655 .

[5] Marefat R, Saberi M, Abdolmajid A, Zoodranj M. A survey on collaboration rate of authors in presenting scientific papers in Koomesh journal during 1999-2010. Koomesh 2012; 13: 279-286. (Persian).

[6] Kalita D. The scientometrics of nature. J Sci Res 2016; 5: 123-134.

[7] Zhang CC, Zheng X, Su CH, Huang H, Yan FR, Pan XJ, et al. A bibliometric study of the Journal of School Health: 1965-2014 Chin Nurs Res 2017; 4: 75-83.

[8] Ansari M, Karimi M, Fallah M, Lotfi S, Valinejadi A. Scientific cooperation networks of Semnan university of medical sciences in the web of science database between 2013-2017. Koomesh 2019; 21: 1-10. (Persian).

[9] Saberi MK. Open Access Journals with a view of journals covered in ISI. Inform Sci Technol 2009; 24: 105-122.

[10] Mohseni M. Investigating the external and internal problems of scientific journals in Iran. J Acad Librari Inform Res 2002; 36: 41-71.

[11] Mirhaghjoo-Langroodi S. Evaluation Scintometric of Quran Studies Magazine. Quran Studi Quarterly 2013; 4: 141-155.

[12] Hart RL. Collaborative publication by University librarians: An exploratory study. J Acad Librari 2000; 26: 94-99.

[13] Low WY, Ng KH, Kabir MA, Koh AP, Sinnasamy J. Trend and impact of international collaboration in clinical medicine papers published in Malaysia. Scientometrics 2014; 98: 1521-1533.

[14] Stvilia B, Hinnant CC, Schindler K, Worrall A, Burnett G, Burnett $\mathrm{K}$, et al. Composition of scientific teams and publication productivity at a national science lab. J Am Soc Inform Sci Technol 2011; 62: 270-283.

[15] Abramo G, D'Angelo CA. The relationship between the number of authors of a publication, its citations and the impact factor of the publishing journal: Evidence from Italy. J Informetrics 2015; 9: 746-761.

[16] Huang MH, Wu LL, Wu YC. A study of research collaboration in the pre-web and post-web stages: A coauthorship analysis of the information systems discipline. J Assoc Inform Sci Technol 2015; 66: 778-797.

[17] Mokhnacheva YV. The influence of various forms of coauthorship on the scientific productivity of Russian scientists in the field of molecular biology. Sci Technic Inform Proces 2015; 42: 162172.
كومش مىتواند كوياى حضور مؤثر اين مجله در جامعه علمى

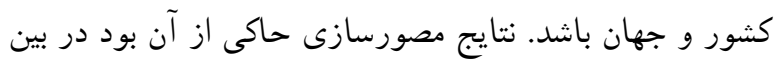

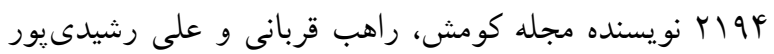
در مركز نقشه و اثركذارتر از ساير نويسندكان هستند. نقشه رئه

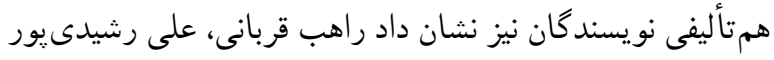

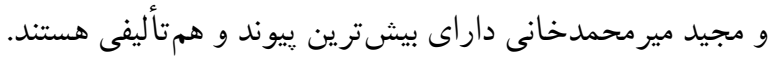

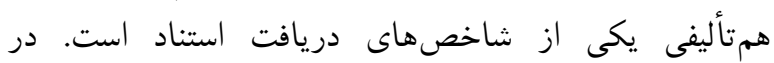

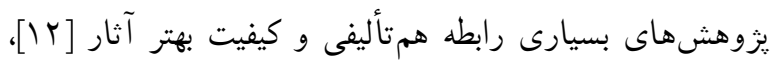

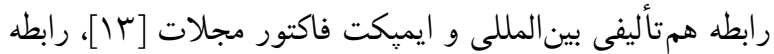

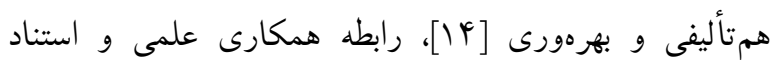
[10،19،1V]

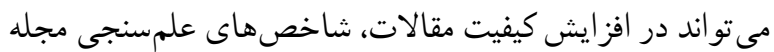

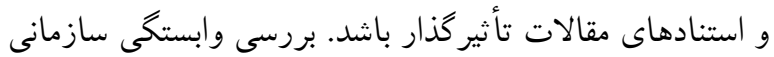

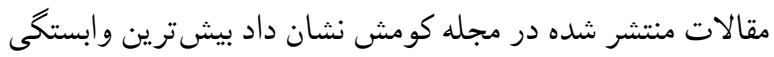
سازمانى به دانشخاه علوم يزشكى سمنان و كشور ايران تعلق درئق

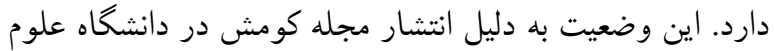

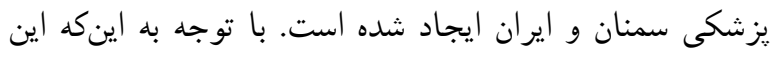

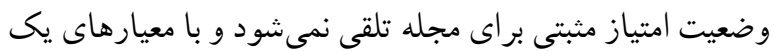

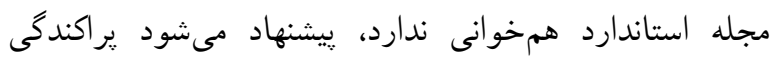

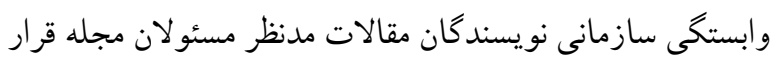

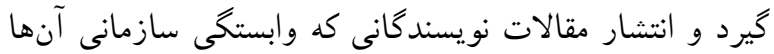

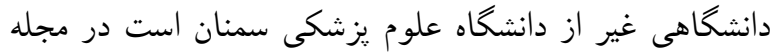

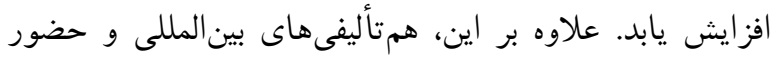
بيثتر نويسندكان غيرايرانى مى تواند استنادهاى دريافتى مجله را افزايش دهد. بر اين اساس شايسته است مسئولانان مجله

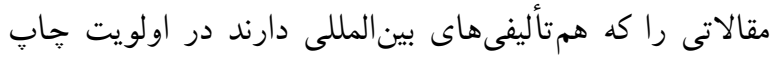
قرار دهند. نقشه همرخدادى كليدوازههاى مقالات منتشر شده در داري مجله كومش نشان داد بربسامدترين كليدوازهها در سه خوشه

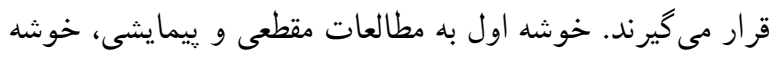
دوم به مطالعات آزمايشگاهى و خوشه سرانه سوم به مطالعات

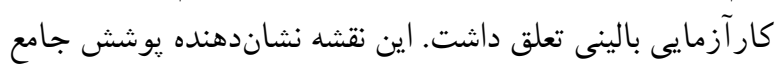

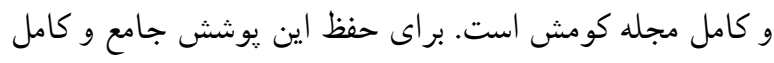

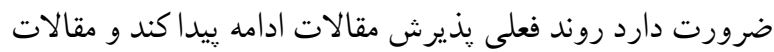

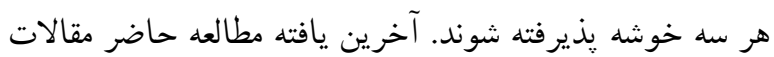

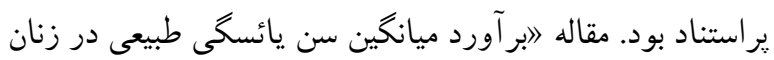

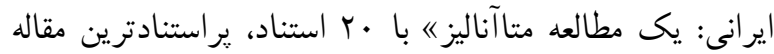

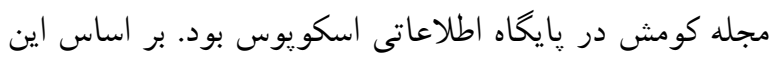

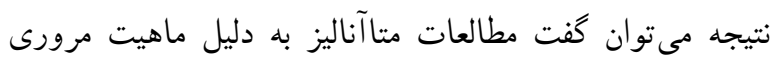

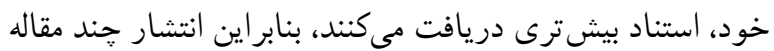
مرورى و سيستماتيك در هر شماره مجله كومش مى تواند داند در

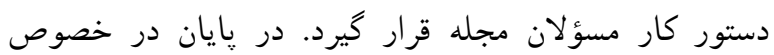




\title{
Visualization of the Koomesh journal between 2006 and 2017: A bibliometric study
}

\author{
Mohammad Karim Saberi (Ph.D)*1, Sepideh Sahebi (B.Sc)2, Mohammad Zerehsaz (Ph.D) ${ }^{3}$ \\ 1 - Department of Medical Library and Information Sciences, School of Paramedicine, Hamadan University of Medical Sciences, Hamadan, Iran \\ 2 - Student Research Committee, Hamadan University of Medical Sciences, Hamadan, Iran \\ 3- Department of Knowledge and Information Studies, Faculty of Psychology and Education, Kharazmi University, Tehran, Iran
}

* Corresponding author. +989129587013 mohamadsaberi@gmail.com Received:29 Dec 2018; Accepted: 13 Aug 2019

Introduction: The present study was conducted with the aim of analyzing the bibliometrics of Koomesh, as one of the oldest and most reputable Iranian medical journals.

Materials and Methods: This study was conducted using a bibliometric method on the articles published in Koomesh during the years 2006-2017. For this purpose, through advanced search in the Scopus database, 764 papers were extracted and bibliometric and Visualization analysis was carried out using Excel and VOSviewer software.

Results: The publication process of articles and citations received by Koomesh is ascending. The number of articles reached from 14 to 100 articles in 2017 and the number of citations reached from zero citations in 2006 to 289 citations in 2017. The co-authorship map of the journal's authors showed that Raheb Ghorbani, with 88 articles and 27 links, was the most active author and had the most co-authorship. Considerably, evaluation of organizational affiliation and contributing countries in the journal articles indicated that Semnan University of Medical Sciences was ranked first with 310 organizational affiliations and authors from nine countries participated in the articles received by the journal. According to the co-occurrence map of all 5424 keywords in the articles published in Koomesh, 127 keywords, which were the most frequent keywords in three clusters, had the frequency of 10 and more than 10 . The article by Abdolreza Raja'i Fard, Abolfazl Mohammadbeygi and Narges Mohammad Salehi, "Estimation of natural age of menopause in Iranian women: A meta-analysis study" with 20 citations was the most cited article of Komosh in Scopus database.

Conclusion: This study presents a general perspective on Koomesh performance during the years 2006-2017. The findings of this study can serve as a roadmap to journalists and assist them in continuing their way.

Keywords: Bibliometrics, Data Visualization. 